\title{
Female Intestate Succession under the Hindu Succession Act, 1956: An Epitome of Inequality and Irrationality
}

Ayushi Singhal*

\section{Abstract}

Under the present legal system of India, people from different religions are governed by their own personal laws in matters of inheritance, marriage, separation, guardianship etc. In this regard, the succession in Hindus is governed by the Hindu Succession Act, 1956 (HSA). A peculiar factor of this Act is that it makes a differentiation between the intestate succession of females and males. The female intestate succession is further dependent on the source from which the property was received by the deceased female. The essay analyses the expediency and rationale behind this differentiation at two levels, one, based on the source of the property and the other, based on gender and elucidates how it is irrational and against the principles of equality on various grounds. It also discusses a recent case, which seeks to bring a progressive change in the law related to succession in Hindus.

Keywords: Female Intestate Succession, Gender Discrimination, Hindu Law, Hindu Succession Act, 1956, Personal Rights.

\section{Introduction}

The property of a Hindu female under the Hindu Succession Act, 1956 (HSA) has been divided into three categories, viz. property inherited by a female from her father or mother, property inherited from her husband or father-in-law and the third kind, the

* Second Year, BA LLB (Hons.), West Bengal National University of Juridical Sciences, Kolkata (WBNUJS); ayushi.singhal95@gmail.com. 
properties which are not governed by the two specific kinds. The first category is a clear example of the obsolete thinking prevalent in the Hindu law wherein woman becomes one with the husband after marriage. This kind of differentiation depending upon the source of property and gender is not seen in any other religion across the world. ${ }^{1}$ The general rule for all kinds of property is that it will pass on to the children (or if children pre-deceased the female, to the predeceased children's children) and the husband. However, in case where there is no one in existence from the predecessors at the time when succession opens, the first kind of property will be inherited by the heirs of her father and the second by the heirs of her husband.2 Perhaps, the intention of the legislature was that the property should revert to the source from which it was received. The subject of enquiry herein, is the succession procedure of the third kind of property, which includes the self acquired property or property received in any other manner or from any other source, provided she has absolute rights in that property.

The act provides for a specific order, in which this property divests:

a) "firstly, upon the sons and daughters (including the children of any predeceased son or daughter) and the husband;

b) Secondly, upon the heirs of the husband;

c) Thirdly, upon the mother and father;

d) Fourthly, upon the heirs of the father; and

e) Lastly, upon the heirs of the mother."3

The above order is highly discriminatory and presents a picture of the archaic thinking of the Indian legislature in so far as the Hindu personal laws are concerned. This will be elucidated in Part III of the essay. Prior to this, Part II will explain the same with the help of

${ }^{1}$ Mohammed Jaheer S/o Abdul Rehman v. M.V. Mohammed Hussain Walayata, (2013) 2 Mah.L.J. 294; DR. POONAM SAXENA, FAMILy LAW LECTURES 363 (3rd ed., 2011).

2 The Hindu Succession Act, 1956, §15.

3 Id. 
the case of Om Prakash v. Radha Charan (Om's case). ${ }^{4}$ Part IV will present the recent developments in this regard and Part $\mathrm{V}$ will conclude the article.

\section{Failure of the Hindu Succession Act}

The case of Om Prakash v. Radha Charan ${ }^{5}$ is an appropriate example of how HSA has failed to prove its robustness. The case pertains to Narayani, after whose death, there was a dispute regarding the succession of her property. Ramkishori, Narayani's mother, filed an application for grant of succession certificate under Section 372 of the Indian Succession Act, 1925. The respondents, who were the brothers of Narayani's husband, also filed a similar application to get the succession of Narayani's self acquired properties. To understand the intricacy of the situation, it is important to know the background of the way in which the properties was acquired.

Narayani's husband died of snakebite within a short period after their marriage. She was then thrown out of her matrimonial place by her in-laws who were the respondents here. She was never enquired of for the 42 years when she stayed in her parents' place after her husband's death. She was educated by her parents and thereafter she gained a well paid job. Therefore, she left a huge amount of property including bank accounts, provident funds, land etc. before she died intestate. The result of this lawsuit however is shocking to the conscience. The judges said that sentiments and sympathy cannot be a guiding principle to determine the interpretation of law and it should not be interpreted in a manner that was not envisaged by the legislature. The court stated that since the HSA specifically mentioned that the self acquired properties will pass on to the husband's heirs in the absence of the husband and any issues, which was the case with Narayani also, the court will have to pass the judgment in favor of the respondents.

This precedent is detrimental to the future cases, owing to the interpretation given to the HSA by the very institution which is held in high regard for the preservation of justice. Although it is

\footnotetext{
${ }^{4} \mathrm{Om}$ Prakash, 2009 (7) S.C.A.L.E. 5: (2009) 15 S.C.C. 66.

5 (2009) 15 S.C.C. 66.
} 
understandable that the court could not have gone beyond the intention of the legislature, however, the court did not completely endorse the Parliament's intention either. The argument of the counsel for Narayani's mother holds weight in this regard. It was argued that since the intent of the Parliament while introducing the said section was to send the property back to the source and not to a stranger, ${ }^{6}$ it is logical that since the property was earned via the money spent by Narayani's parents, the money so earned should be returned to her parents. This however was not accepted by the court.

The judgment can be criticized on another ground, which is the ignorance of the principles of equity, justice, good conscience and public policy. ${ }^{7}$ It should be noticed that the succession laws are not only about the ones who are entitled to the property, but also about the ones who should be disentitled. Mulla ${ }^{8}$ observes that Section 15(2) is based on the ground that property should not pass to the individual whom justice would require it should not pass. Here, the court granted the property to the very people who behaved cruelly towards her and did not maintain the relationship when she needed it the most. The respondents recognized the relationship between themselves and the plaintiff only when there was a scope of benefitting from this relationship. They deserved punishment and not reward. The court should have denied them the locus standi of asking the property of a person ${ }^{9}$ who they had disregarded for more than four decades. One could draw support for this argument from Section 25 of the HSA, where a murderer is disqualified from inheriting the property of the person he/she has murdered. It is based on the belief that the deceased person will never want the person who murdered him/her to inherit property.

\footnotetext{
${ }^{6}$ SR Srinivasa v. S Padmavathamma, (2010) 5 S.C.C. 274.

${ }^{7}$ SAXENA, supra note 1 at 371.

8 Sir DinshaW FARdunji Mulla, Principles of Hindu LAW (LexisNexis Butterworths, 21st ed., 2013).
}

${ }^{9} \mathrm{Id}$. at 372. 
However, the impugned case is not the only one where neither the intention of the legislature, nor that of the intestate was respected..$^{10}$ The law as laid down might have some inherent flaws itself. The subsequent section analyses the same.

Hindu law is one of those very few personal laws in India, which has changed with the change in time. It was a subject of criticism before the Hindu Code Bill was passed, because of the glaring inequalities that existed in the law. ${ }^{11}$ However the code was not able to make up for the inequalities and had to be edited with a stride of amendments. However, the various amendments made in the HSA as an attempt to make it more and more progressive have not been able to bridge the gap. Disparities remain, especially the ones which stem from the patriarchal nature of the Hindu society. These are so subtle, that not only are the women discriminated against, but also their close heirs are, as has been seen above. This is a failure of the mechanism in HSA, which is believed to treat both genders on an equal scale. ${ }^{12}$ The Act has not been able to achieve the basic characteristics of a good succession law.

Any rational code of intestate succession must be based on the following principles:

a) there must be one rule of inheritance whether the intestate is male or female;

b) the rule must be the same whatever be the nature of acquisition of property by the intestate;

c) there must be gender equality;

d) the husband, and the wife must have mutual and equal rights; and

10 Satyacharan v. Urmila 1970 S.C. 1714; Ayyi Ammal v. Subramanya Ansari 1966 Mad. 369; Veera Raghagvamma c. Subba Rao (G) 1976 A.P. 377.

11 Prabbha Sridevan, A Law that Thwarts Juctice, The Hindu, (Jun. 26, 2011). available at: http://www.thehindu.com/opinion/lead/a-law-thatthwarts-justice/article2137110.ece.

12 The Hindu Adoption AND MAINTENANCE ACT, 1956, Statement of Objectives and Reasons. 
e) the father and the mother must be placed in the same position. ${ }^{13}$

In contrast to the Parsi, Muslim or Christian law, where the blood relatives of the women inherit even in the presence of her husband or her husband's relatives, the blood relations of a Hindu woman are given an inferior position in contrast to her husband's heirs. This leads to a situation where her own relatives will not be able to inherit in cases where even if there is a remote heir of the husband. ${ }^{14}$ The purpose of succession law, i.e. "in the absence of any express ... instructions of the deceased such a distribution should be effected of her property that she in normal course as a reasonable person would make of her own property"15 is not then met by the law as stated. Some scholars try to trace its origin to the fact that women leave the natal place and with that all the natal relations to her husband's place. However, this explanation is hard to accept, when this practice of leaving the natal home by the women is practiced almost all over the world, ${ }^{16}$ even in the most progressive religions; yet, there the laws are not as discriminatory as that of Hindus.

The Hindu law is at a juncture, where women after the entire struggle to inherit property are now unable to divest it the way they would have wanted had they been alive. ${ }^{17}$ The right to make a will does not come to rescue, since Indian women's education has not yet seen the light of the dawn. The ignorance of law by the Indian society further discourages the writing of a will. A justification for Section 15(2) of HSA can still be found in the fact that the Joint Parliamentary Committee while bringing in the clause

13 Justice S A Kader, The Proposed Amendment of the Hindu Succession Act, 1956 - A Half-Hearted Measure, 1 L.W. (J.S.) 129 (2005).

14 SAXENA, supra note 1 at 371.

15 Dr. PoOnam Pradhan Saxena, Succession LaWs and Gender Justice IN REDEFINING FAMILY LAW IN INDIA 290 (Archana Parashar and Amita Dhandha, ed., 2008).

16 SAXENA, supra note 1 at 371.

17 PREM CHOWDHARY, CONJUGALITY, LAW AND STATE: INHERITANCE RighTS AS PIVOT OF CONTROL IN NORTHERN INDIA IN DOWRY AND INHERITANCE (Srimati Basu ed., 2005). 
wanted the property to be transferred to the source. ${ }^{18}$ However, it is difficult to draw an analogy for the same in Section 15(1), since no source can be indicated for a woman's self acquired property. In such a situation, it is an established practice and appeals to logic, that the blood relations will be preferred by a person over the distant relatives of the spouse (even when we may consider inheritance by the husband and children as legitimate).

The present law is also an epitome of gender inequality. The property of a male intestate devolves on blood relations and relations by marriage and do not extend to the relationship of the spouse. ${ }^{19}$ However in the case of females, there is judicial imposition of the husband's relatives over her blood relations. The entire group of husband's heirs inherits from her, whereas she does not inherit from them. The marriage of a man does not make a difference on the way his property gets devolved, but the marriage of a woman changes the pattern of inheritance for her property. This is a result of the thinking that a woman has no family of her own, it is either the husband's or the father's that she lives in. A woman is not treated as an independent individual capable of transferring her property to her blood relatives, but an extension of her husband. It strips her off her true identity, under the existing identity crisis under the HSA. This position that the wife merges with the husband on marrying cannot be justified in the $21^{\text {st }}$ century, even as a way to preserve the Hindu culture; where woman have become economically independent and do not depend on their husbands anymore. ${ }^{20}$

The law is also a suggestion of the discarded view that the woman has a limited stake in the property. This view which was sought to be discarded by Section 14(1) of the HSA, still haunts the lives of the Hindu women, where the property held by the women should return to the source she received it from.

18 207th Law Commission of India Report, Proposal to amend Section 15 of the Hindu Succession Act, 1956 in case a female dies intestate leaving her self-acquired property with no heirs, (June, 2008)).

19 The Hindu Succession Act, 1956, Schedule I and II.

20 SAXENA, supra note 1 at 372. 
There has not been an effort to rationalize the source of the self acquired property of the Hindu women. In the case of old Hindu families, there was a trend that women were generally the home makers and only men earned; however, the law has failed to keep abreast with the recent changes in the concept of a Hindu family. In contemporary India, the joint family system has eroded and there has been a shift towards the nuclear families in the past few years. Therefore, the closeness to and dependence on the natal family is more than the closeness to the matrimonial home. In such a situation, there are times, when the husband and wife live by themselves and do not meet the relatives throughout their married life. Therefore, it is illogical and against the principles of succession law that the relatives of the husband inherit the property. As in the case illustrated above, even if the deceased woman is ill treated by the husband's mother and father, they inherit the property instead of her own parents. This is so when most women will prefer that their parents inherit their property over their in-laws in the absence of husband and issues. ${ }^{21}$

The preference of a son in the Hindu society can also be traced to such kinds of laws in India. It should be seen that under the present law, it is only through males that the blood relatives can inherit and not through females. ${ }^{22}$ Parents of a single girl child thus, have no security of inheritance unless the girl child makes a will. On the other hand, the parents of a male child are included in the succession scheme where mother is included in the list I heirs and the father in the II. A mother shares equally with the children and the widow when a son predeceases her. In such a situation, the parents of a male child are better off than that of a female's resulting in the bias. These failures in the present system demand for a reform in the law. The case discussed in the next section is a welcome step in this regard.

21 Supra note 16.

22 SAXENA, supra note 1 at 371. 


\section{Progression in the Law Pertaining to Female Intestate Succession}

The case of Mamta Dinesh Vakil v. Bansi S. Wadhwa ${ }^{23}$ is a watershed judgment towards introducing reforms in the female intestate succession laws among Hindus. The case is a regular female intestate succession issue, however one of the few to challenge the constitutionality of the law as it stands today. It challenges the validity of Section 8 and Section 15 of the HSA. Fortunately, the judiciary this time did not bow down to the black letter law as in Om's Case, ${ }^{24}$ but upheld the constitutional principles of equality as enshrined in Article 15. However to understand the basis of the judgment, one needs to understand the principles on which affirmative discrimination is made in the law.

It is a rule of law and an established principle in our Constitution that discrimination cannot be made against any citizen on grounds only of religion, race, caste, sex, place of birth or any of them..$^{25}$ This being the case, discrimination based 'only' on the above grounds is unconstitutional, but not the one which is based on the above factors coupled with some other criteria like social and educational backwardness. This is the very reason why affirmative action like reservations based on caste, are not violative of Article 15 of the Constitution. Extending this proposition and relying on the above sections of the HSA, it was argued that the inequality which exists in Section 15(1) of the Act is not based on gender alone but also on family ties. Building it further, it was said that, "the woman, upon marriage, goes into the family of her husband; the converse is not true. A woman gives up her maternal/paternal ties upon her marriage and assumes marital ties. Hence, intestate succession for Hindus takes into account this ground reality." 26 Considering this reality, the legislature has provided for the heirs of the husband in the woman's property.

It needs to be noticed that the constitutional validity of the section in question was also bought to the judiciary in an earlier case of

${ }^{23}$ Mamta Dinesh Vakil, T.S. 86/2000-T.P. 917/2000.

${ }^{24}$ Om Prakash v. Radha Charan, (2009) 15 SCC 66.

${ }^{25}$ The Constitution OF INDiA, Art. 15.

${ }^{26}$ Mamta Dinesh Vakil, T.S. 86/2000-T.P. 917/2000. 
Sonubai Yeshwant Jadhav v. Bala Govinda Yadav.27 It was held there that "the object of the legislation was to retain property with the joint family upon marriage which brought males and females together forming one institution. It, therefore, accepted that in recognition of that position when the wife's succession opened, the class known as heirs of the husband were permitted to succeed as a result of initial unity in marriage upon which the female merged in the family of her husband".

However the court in the present case, rejected this argument, and added that the discrimination in the section is only based on gender and not on family ties. The court analyzed the succession scheme of the male intestates under the HSA to check the viability of the argument. It noticed that keeping the property within the family was not being envisaged; otherwise daughters, sister's sons and sister's daughters would not inherit the property of a male Hindu. It was held that if the Parliament envisaged keeping the property within the family, it would not have wanted the sisters and the daughters to inherit from the male's property, since they are married off to homes of other people. It was thus concluded that the only basis of this classification was gender. The section is extremely discriminatory in as much as the female's property even if self acquired is not inherited by her core heirs. Further a Hindu female who would expect to inherit from the estate of another receive(s) setback from distant relatives of husband of deceased not even known to her or contemplated by her to be her competitors. Therefore the section is ultra vires the scheme of the Constitution and hence invalid.

The aspect that the judiciary should not interfere in personal laws was also brought up. The court considered it a blemish to have discriminatory succession laws even when the Hindu society was thriving towards gender equality. It was said that a legislation, which is discriminative only on the basis of gender, can be questioned, as was done when Section 10 and Section 34 of the Indian Divorce Act, 1869 were amended. ${ }^{28}$ Moreover, there have

27 Sonubai Yeshwant Jadhav, A.I.R. 1983 Bom. 156.

28 Ammini E. J. v. Union of India, A.I.R. 1995 Ker 252; N. Sarda Mani v. G. Alexander A.I.R. 1988 A.P. 157. 
been progressive changes in the Hindu law itself, e.g. the amendment in Section 6 giving women the right to coparcenary and deletion of Section 23 which deprived women of sharing the dwelling house by the 2005 amendment. ${ }^{29}$ It was recognized that although there can be different laws for different religions, there cannot be different laws for different sexes and thus the judiciary has a right to interfere in the latter case.

Although a magnum opus of the justice is done by the judiciary, this judgment passed by a single bench of the High Court needs to be affirmed by the division bench. Once it is so done, it will be a watershed judgment to bring in equality in the Hindu law pertaining to succession. Once declared unconstitutional, the government can use the recommendations of the 207th Law Commission Report 30 to bring reforms in the law. The report suggests two options, one, of bringing the intestate succession laws in parity with the males, and the other, of dividing the property equally among the matrimonial and natal heirs taking into account the ground reality that the women ultimately leave their natal place and work under the constant support of her in-laws. Either of these options will be progressive changes in the Hindu law.

\section{Conclusion}

The scheme of female intestate succession in the case of Hindu law is extremely discriminatory and irrational in terms of the purpose of an ideal succession law. The present law has led to arbitrary results, where the property passes on to the person, whom if the intestate would have been alive, would have never wanted her property to devolve upon. This unconstitutionality of the law has also been recognized in the case of Mamta Dinesh Vakil v. Bansi S. Wadhwa. ${ }^{31}$ The case however is pending before a division bench of the High Court of Bombay. The law so changed, will help in reducing the existing arbitrariness and bring in progressive changes in the legislature.

${ }^{29}$ The Hindu Succession (Amendment) Act, 2005 § $3 \& 4$.

30 Supra note 16.

31 T.S. 86/2000-T.P. 917/2000 